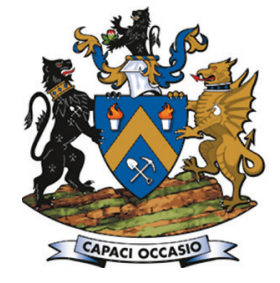

Affiliation:

1 Graduate School of Technology Management, University of Pretoria.

2 University of Johannesburg.

Correspondence to:

G. Bekker

Email:

giel.bekker@up.ac.za

\section{Dates:}

Received: 2 Oct. 2019

Revised: 26 Jan. 2021

Accepted: 23 Feb. 2021

Published: May 2021

How to cite:

Smith, W.A., Bekker, M.C., and

Marnewick, C. 2021

Projectification in the South

African mining industry.

Journal of the Southern African

Institute of Mining and Metallurgy,

vol. 121, no. 5, pp. 217-226.

DOI ID:

http://dx.doi.org/10.17159/2411-

9717/950/2021

ORCID

G. Bekker

https://orchid.org/0000-0002-

4837-2677

C. Marnewick

https://orchid.org/0000-0002-

2340-8215

\title{
Projectification in the South African mining industry
}

\author{
W.A. Smith ${ }^{1}$, M.C. Bekker ${ }^{1}$, and C. Marnewick²
}

\section{Synopsis}

Projects or project-orientated approaches have become a common form of work in nearly all sectors of economies. This has led to concepts such as 'projectified' and 'project orientated' organizations. By defining projectification of a company, industry, or economy as the share of project work in total work, one can reasonably determine the impact that project management, and by default projectification, has had on that company, industry, or economy in terms of staff optimization and allocation.

This paper presents the results for such a projectification study of the South African mining industry. This sector has long been a significant contributor to the country's economy from a gross value added (GVA) and employment point of view. Understanding the impact of projectification and the project management way of work on this industry may potentially add significant value to both the mining and project management knowledge areas.

We show that although the mining industry is considered by some to operate in archaic ways, the level of projectification has increased over time, and now represents approximately one third of all work conducted.

\section{Keywords}

rojectification, mining projects, project management, project management office.

\section{Introduction}

The mining industry in South Africa has long been a significant contributor to the economy from a gross value added (GVA) and employment point of view. The mining industry in South Africa includes quarrying, underground, and open pit, as well as hard and soft rock mining operations. These different types of operations are divided into the following categories by commodity:

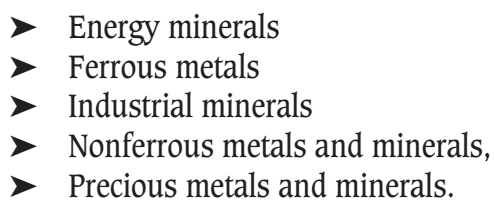

For the purposes of this paper, the mining industry in South Africa is considered as mining companies that are typically production orientated. This definition excludes consulting and construction companies, original equipment manufacturers (OEMs), and other equipment suppliers and service providers. The intent was to review what approach is taken to conduct work by production orientated businesses in the mining environment, and this was encapsulated by information received. The impact of the abovementioned sectors is important but was deliberately excluded at this time to isolate mining companies. However, the intent is to follow-up this study with a paper covering the other disciplines in the mining environment and their impact on global projectization of the full value chain of mining.

Mining operations can also be divided into a two 'spheres of technology' application; first where some organizations insist on digitalization drives that increase the automation of work, and second where others do as little as possible to drive change towards digital applications. The drive for digitalization and expansion in mining in South Africa may be seen as a catalyst for the projectification of the South African mining industry. The improvement in technology is providing the opportunity for changes in operational philosophy and thus the commissioning of an increasing number of projects.

According to ISO 21500 (2012) a 'project' can be defined as a 'unique set of processes consisting of coordinated and controlled activities with start and end dates, performed to achieve project objectives'. In the mining sector projects are more than the development of a new mining reserve, processing plants, materials handling, or other capital infrastructure. Projects in this sector, as with other capital-intensive industries, also include information technology, business optimization, stay-in-business, safety, environmental, and other compliance-related initiatives. 


\section{Projectification in the South African mining industry}

A project includes various management activities and therefore project orientated approaches have become a common form of work in nearly all sectors of economies. This has led to concepts such as 'projectified' and 'project orientated' organizations (Schoper et al., 2018). Brenin and Soderlund (2006) defined 'projectification' as a 'general development process in which firms to a greater extent focus their operations on projects, project management and various types of projectlike structures'. Projects, and the management thereof, are often centralized in project management offices (PMOs). However, the extent of projectification in mining organizations in comparison to the regular way of work has, as far as the authors are aware and based on a literature survey, never been systematically examined. The lack of projectification research in the mining industry could be due to its production- and maintenanceorientated nature. Understanding the impact of projectification on budgeting, human resources, and organizational structures may provide valuable insights into the level of projectification that can or should be allowed in an organization. Projectification is not fully understood in the mining industry in South Africa. Clarification on the level of projectification can address resource allocation issues that may occur in the industry.

The research objective is to understand the functional and operational activities of organizations in the mining industry in South Africa, specifically related to project work. Based on these definitions, the levels of projectification in organizations can be measured by obtaining information on the time and capital spent in the project environment. To fully comprehend the levels of projectification in the South African mining context, this publication attempts to answer the following questions:

1. Do mining companies have formal project structures such as project management offices (PMOs)?

2. What percentage of the company's working time is used for projects?

3. What percentage of the South African mining industry can be regarded as projectized?

4. How does South Africa compare with developed economies in this regard?

\section{Literature survey}

In order to contextualize the content of this paper, some projectrelated definitions need to be clarified. Adding to the ISO 21500 definition, Nicholas and Steyn (2017) defined a project as a unique activity, conducted by a temporary organization with a specific set of desired deliverables that must be achieved within a fixed time frame to realize specific benefits Projects are initiated and managed within an organizational environment and therefore a project-based organization is defined as one that conducts its main external and internal activities by means of projects (de Rooij, Janowicz-Panjaitan, and Mannak, 2019). Project management is the application of knowledge, skills, tools, and techniques to execute project activities to achieve project goals as per the project definition (Nicholas and Steyn, 2017). The project management process can be divided into five stages: namely initiation, planning, execution, monitoring/control, and closure. This leads to the magnitude of projectification being considered as the share of project work in an organization with respect to the total amount of work done. (Schoper et al., 2018)

\section{The origin of project management theory}

Weaver (2006) traces the inception of project management philosophy back to the 15 th century when the Protestants, later referred to as Puritans, presented the ideas of reductionism, individualism, and the Protestant work ethic (PWE), which reverberates significantly in modern project management theories as Puritanism (Whitty and Schulz, 2007). The definitions of and differences between these concepts are provided in the following paragraphs.

According to Weaver (2006), reductionism in project management places emphasis on the removal of redundant or unnecessary elements within a specific process as a means of formulating an understanding of its functionality. Reductionism therefore refers to a practical approach through which a phenomenon is understood by reducing it to simpler individual constituents. Whitty (2009) agrees that reductionism is 'heuristically useful' and emphasises that in a traditional sense, project management is executed by means of a 'conscious initiative' where reductionism is actively applied to make sense of project environments.

Individualism, according to Weaver (2006) 'assumes that we are active, independent agents who can manage risks and create ideas'. The ideas generated through individualism are subsequently transformed into action, which as noted by Altinkaya (2006) is more prevalent in modern developed economies.

The third theoretical concept that shaped Puritanism is that of the PWE. According to Whitty and Schulz (2007), prior to the initiation of the PWE, developed societies perceived their role in the work force as a 'necessary evil' rather than a 'calling'. The transformation associated with the PWE contributed to the success of early economic development and capitalism and is known as a value-based work ethic that believes in the moral benefit of work and its ability to enhance character.

From an evolutionary perspective, the theologies that have shaped Puritanism throughout history have been further incorporated into two key philosophies namely, liberalism and Newtonianism (Weaver, 2006).

Liberalism has transformed project management theory through renewed teachings of Puritanism that sparked a work ethic that drives the economic traits of capitalism (Whitty and Schulz, 2007).

In conjunction with liberalism, Newtonianism initiated the era of scientific enquiry where scientific observations provided vital insight in terms of various phenomena. Both liberalism and Newtonianism philosophies have influenced the scientific management theory of Taylor, a vital influencer on modern project management known as Taylorism (Figure 1).

The inception of modern project management is strongly linked to the development of scientific management theory by Frederick W. Taylor, later referred to as Taylorism. Taylor (Shenhar and Dvir, 2004; Drob, 2009) hypothesised around scientific management principles and applied scientific reasoning to the application of labour analysis and improvements on the elementary components associated with it.

According to Whitty and Schulz (2007), Taylorism 'marked an era of efficiency. From a corporate perspective; work was to be systemised, efficiency glorified, and the managerialism doctrine would complete the foundation for the spirit of project management'. Taylor's management system brought on project management innovations in the field of industrial engineering when his influential swork (The Principles of Scientific Management, published in 1911) led to dramatic improvements 


\section{Projectification in the South African mining industry}

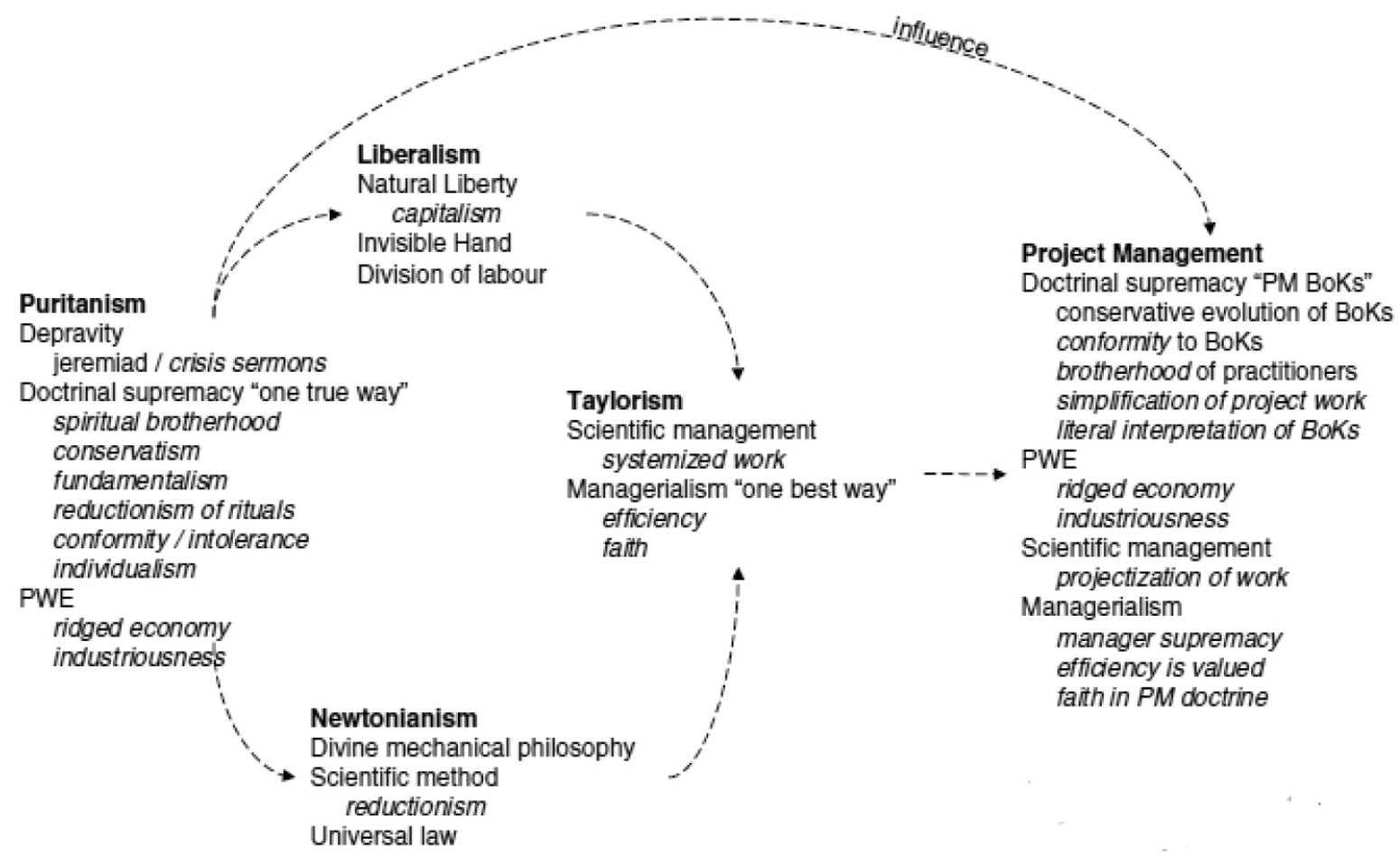

Figure 1-Evolution of Puritanism (Whitty and Schulz, 2007)

in productivity. Taylor's research was largely motivated by the need for greater competence and efficiency. This is the cornerstone of project management as a field of study.

Although the idea of project execution as an arranged activity can be found in almost every civilization in history, aspects associated with the evolution of project management theories and its buildup towards a modernized practice were first implemented in the USA in the twentieth century (Drob, 2009). The prevalence of project management application and theory became increasingly significant as a result of the benefits realized through organizing work based on projects and understanding the need to "communicate and integrate work across multiple departments and professions' (Shenhar and Dvir, 2004).

Cicmil, Lindgren, and Packendorff (2016) state that projectbased companies in modern society often employ Taylorist strategies to improve human performance, labour utilization, and productivity. Furthermore, Metcalfe (1997) emphasises that project management practices facilitate greater managerial control within modern organizations. To further comprehend these concepts, it is necessary to understand classification of projects, and how this influences the type of PMO and eventually the levels of projectification in an organization and industry.

\section{Classification of projects}

The classification of projects is necessary to understand the vast project management realm. Crawford, Hobbs, and Turner (2006) identified three groups of project classifications:

> Size, risk, or complexity

- Strategic importance, stage of the life cycle, or sector

> Contract form, payment terms, or risk ownership.

Various reasons exist for each classification or group classification like resource management practises, strategic importance, organizational structure management, and financial investment selections. For the purpose of this research, the
Table I

Payne and Turner (1999) project classification by size

\begin{tabular}{|l|c|}
\hline Classification & Cost as \% of company turnover \\
\hline Small & $0.1 \%$ \\
Medium & $1 \%$ \\
Large & $10 \%$ \\
Major & Company turnover \\
\hline
\end{tabular}

monetary value of projects is important and therefore the classification based on the capital value approach by Payne and Turner (1999) was used (Table I).

This classification of projects has an impact on the management style of projects. The set-up of managementstructures and/or temporary organizations to manage projects of different classes changes the value proposition of such projects. The classification of different projects is imperative to the management thereof and the eventual impact on projectification of organizations.

\section{Project management office and the value added}

According to Aubry, Hobbs, and Thullier (2007), the most common reaction to the management of multiple projects in organizations is to implement a PMO. Cooke-Davies, Schlichter, and Bredillet (2001) emphasised that 'there is a growing recognition that project management involves more than the skillful and competent management of individual projects. It also requires a set of systems, processes, structures, and capabilities that enable an organisation to undertake the right projects and to support them organisationally.' Therefore, the role of a PMO in an organization and the development of that PMO in any organization must be closely linked to the type of business and the generic rules and practices of that industry. 


\section{Projectification in the South African mining industry}

According to van der Linde and Steyn (2016) the value added to organizations by PMOs, or project management as an action, can be attributed to three areas:

> Where the PMO fulfils the purpose of adding value to the organization through formal project management practices

- The level of value-creating capability the PMO has in an organization

> The level of key performance indicator (KPI) improvement due to PMO involvement in projects.

Similarly, Crawford and Pennypacker (2001) found that implementing PMOs adds significant value to an organization. The average improvements claimed are:
- 54\% in financial performance
> $50 \%$ in project/process execution
> $36 \%$ in customer satisfaction
> $30 \%$ in employee satisfaction.

It is accepted that the value added by a PMO of the right composition and type in an organization can have a positive impact on project performance in terms of time, cost, and quality of the product, facility, or service. The PMO could also determine the level of projectification of an organzation by influencing the strategic decision-making processes.

\section{Projectification}

The term projectification first appeared in the literature in 1995 when Midler (1995) conducted a case study into the organizational changes at Renault. Bredin and Söderlund (2011) define projectification as a move from repetitive production to non-routine work processes and the use of temporary projects. Schoper et al. (2018) define projectification as the share of project work in an organization's activities.

Together with the earlier definition of Brenin (2006), projectification can be considered as the conducting of work, either routine or unique, in the form of a project. This is contradictory to the definition of a project as a unique process (Lester, 2017) or task. However, projectification has considerably changed the definition of what is deemed a project, way beyond the definitions given in the literature (Maylor et al., 2006).

Projectification in organizations passes through four phases, identified by Midler (1995) as:

- Starting as a functional organization with informal project coordination

- Establishing centralized project coordination and project coordinator roles

> Establishment of project management structures through empowerment and autonomy of project managers

- Finally, a transformation of organizational processes, practices, incentive systems etc. into a balance between functional and project work.

Projectification thus goes further than pure organizational changes; it concerns a fundamental organizational transformation from the point of view where project work is a tool to achieve organizational goals.

The projectification of an organization is based on the view that organizational structure changes will provide solutions for certain types of tasks. This phenomenon can be linked to the Organization Theory in the context of scientific management. This theory refers to the need to handle non-routine and specialized tasks differently from standard production-type tasks (Packendorff and Lindgren, 2014).
Maylor et al. (2006) revealed that the increase in restructurings relates to or indicates an increase in projects being executed. They also refer to the increased reliance on standardization of operational frameworks and the increased prevalence of PMOs. The performance of these offices is directly linked to the perception of performance of the organization. Drawing on the conclusions made by Schoper et al. (2018) and the assumption that the links between industries, their contribution to economies, and the level of projectification are correct, it could be expected that similar results can be achieved in the South African context.

\section{Mining industry operational model}

In the mining industry projects are clustered in several categories to satisfy the different areas of operation. Mining operations, engineering operations, beneficiation plants, information management, and new business development all launch projects from time to time to ensure continuous production. The addition of PMOs in large organizations, in this case mining organizations, has significantly contributed to the success of projects and the organizations at large (Aubry, Hobbs, and Thiollier, 2009).

Different project management methodologies have also been tested in the South African mining industry. Phillis and Gumede (2009) tested the effectiveness of the critical chain project methodology in a mining application with relative success, and the work by Nelwamondo and Pretorius (2018) illustrated that project management methodologies can be employed to 'break the boundaries of traditional management'. This testing of the project way of work, the implementation of PMOs, and by definition the projectification of the mining industry warranted further research into the impact it has on the sector.

To understand the impact of projectification in the South African mining industry, it is important to understand the different organizational structures and projectification as a process or structure change. It also important to understand what is considered project work.

The typical functional organizational structure of a production environment, is compartmentalized into functional and skillbased departments (Midler, 1995). Each department has a function to perform and does not venture outside the boundaries or mandate of that department. Figure 2 depicts this typical functional organization.

With increased emphasis on working safer, cleaner, and more effectively, cross-functional performance of work is required to execute more complex tasks or essential projects. Most firms operating in such a multi-project environment have adopted a matrix organizational structure for the fast and cost-effective execution of such projects (van Staden, Steyn, and Schnetler, 2015). In a production environment this remains a challenge, with responsibility conflicts that are created when daily production goals are meshed with project-orientated goals. Figure 3 graphically represents such an organization.

The functioning of a matrix organization does present some challenges regarding the roles and responsibilities of personnel (Kuprenas, 2003). The most significant challenge is that of balancing responsibility between functional and allocated project work (van Staden, Steyn, and Schnetler, 2015). To address the potentially constraining effect that the matrix-type organizational design has on the execution of work in the mining industry, the 


\section{Projectification in the South African mining industry}

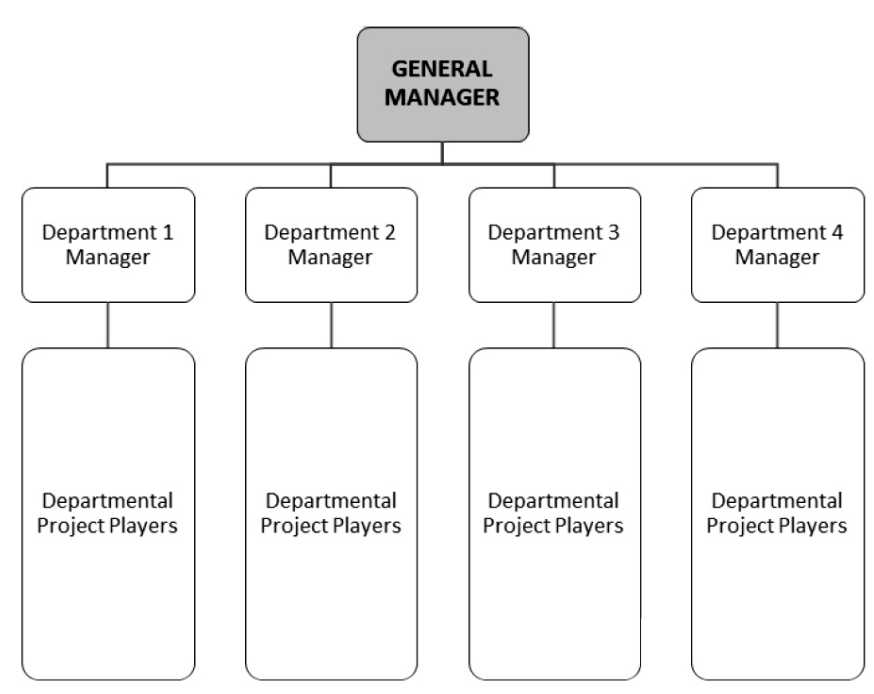

Figure 2-The functional structure (adapted from Midler, 1995)

life-cycle characteristics and fluctuating workload of a project need to be considered and incorporated (Turner and Müller, 2003).

\section{Research methodology}

This research project is deemed to be of the natural paradigm type and thus the decision, or inclination, toward the paradigm of positivist ontology. Positivist ontology, or positivism, holds that the world is external and that there is a single objective reality to any research phenomenon or situation regardless of the researcher's perspective or belief (Hudson and Ozanne, 1988).

Answering the research questions required analyses of data gathered from a survey and thus is inherently quantitative. The South African mining industry is the setting for this research. The setting is expanded to include companies listed on the Johannesburg Stock Exchange (JSE) or that employ more than 150 people. This selection of companies provides a setting where project management duties are generally part of the organization, whether internally or externally sourced.
Figures 4 and 5 illustrate where the research took place in the South African economy and what components of the project management landscape were addressed.

A purposive sampling technique, also referred to as nonprobability sampling, was used in this research. According to Etikan, Musa, and Alkassim (2016), purposive sampling (judgment sampling) is the deliberate choice of a participant due to the qualities the participant possesses. It is a non-random technique that does not need underlying theories or a set number of participants. For this research, the intent was to ensure that the data collected is representative of the largest contributors to the South Africa economy via the South Africa mining industry. In this way the projectification factor can be linked to the economy of the mining industry and the country. The specific sampling was done by retrieving information from Statistics South Africa (STATSSA) on the highest grossing, in terms of turnover, mining companies in South Africa and retrieving data from that population. The threshold for selection was determined

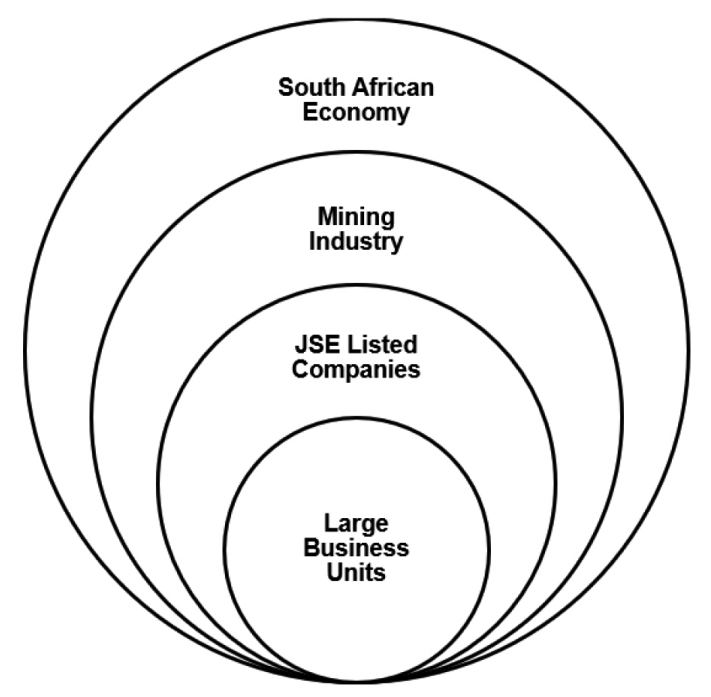

Figure 4-Mining industry and large business units

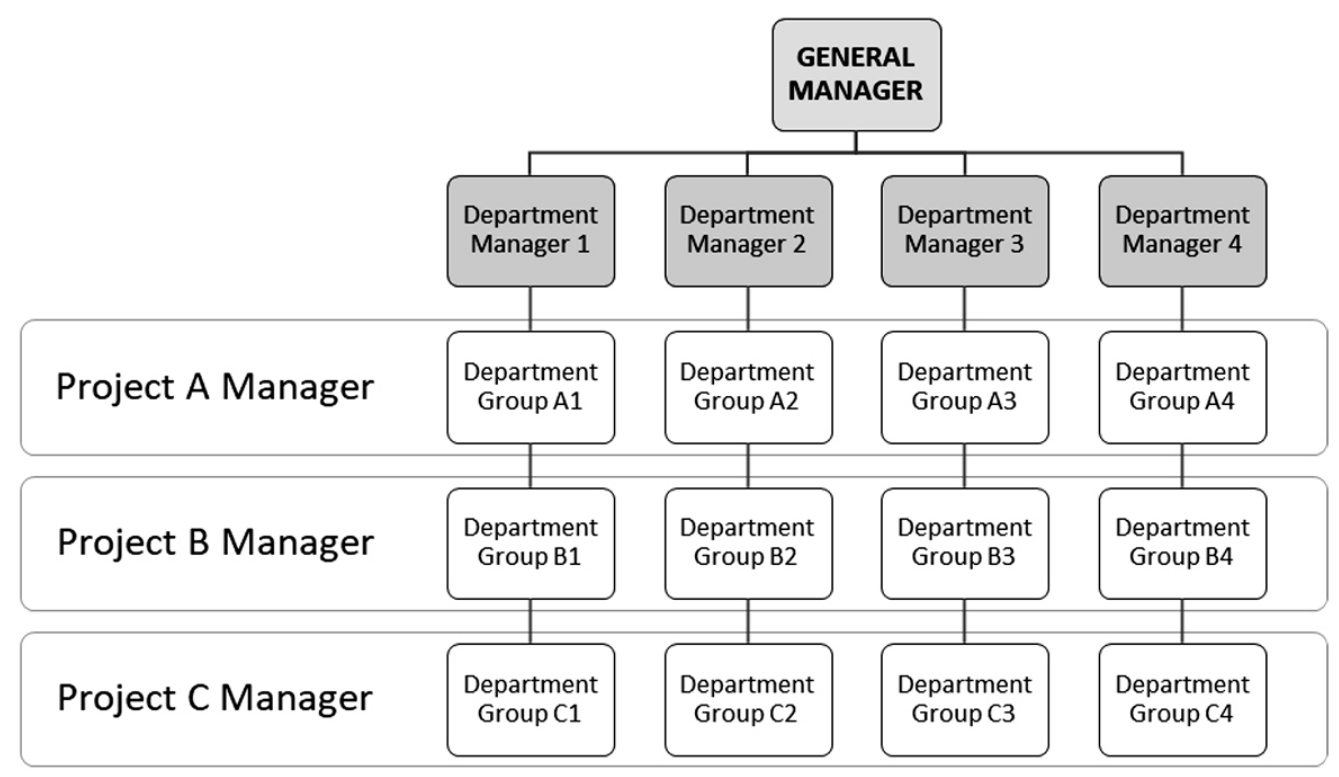




\section{Projectification in the South African mining industry}

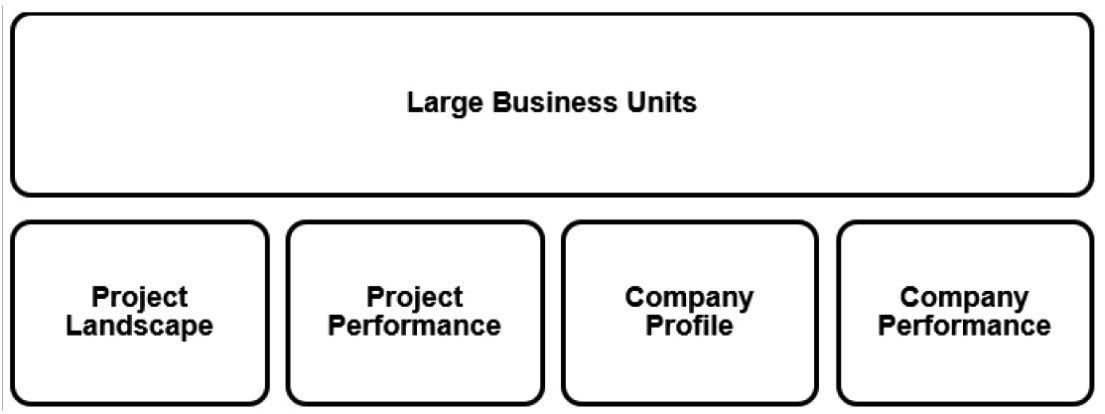

Figure 5-Components addressed in the selected industry

Table II

Attributes to be tested for validity

\begin{tabular}{|l|l|}
\hline Attribute & Verification questions \\
\hline Internal validity & $\begin{array}{l}\text { - What bias exists in the selection of respondents, if any? } \\
\text { - Did the system of measurement change during research? } \\
\text { - Do any of the respondents have a reason to make the study fail? }\end{array}$ \\
\hline External validity & $\begin{array}{l}\text { - Was the survey biased with reference to respondent type? } \\
\text { Reliability }\end{array}$ \\
\hline Objectivity & $\begin{array}{l}\text { - Can the sample representative of the population? } \\
\text { - Can the same results be obtained by a different researcher? } \\
\end{array}$ \\
\hline
\end{tabular}

by JSE listing, employee numbers, or overall contribution in monetary value. In South Africa, the highest grossing mining companies are those in the diamond, gold, and platinum sectors.

\section{Data collection}

The data for this research was gathered by way of an online survey sent to as many potential participants as possible via email. The survey was structured as follows:

> Company details (size, manpower etc.)

- Internal company project landscape, which included all projects and project-related work

> Project and company performance

- Participant details (role in company etc.)

Descriptive statistical analysis was used to analyse the gathered data. Due to the different type of projects conducted in the mining industry, the analysis was based on the Schoper et al. (2018) definition of projectification.

Ensuring the reliability and validity of the data collected is imperative to the success of any research. An attempt to ensure quality of data was made by selecting the person to complete the survey as a person of some authority in an organization. The assumption was that such a person will be well informed on the questions asked and thus a quality response may be expected. Table II describes the attributes and the verification questions that were asked for each question.

The survey process requested respondents to answer each of the questions. There should be high level of confidence that the approach selected is appropriate.

\section{Assumptions and limitations}

Using the same approach as Schoper et al. (2018) to determine the level of projectification in the South African mining industry will result in similar limitations regarding the value added by project work. Because the work input is not equated to a value output in all cases (data to this effect is not necessarily available), the estimation of value added by projects is not exact. For example, mining houses carry out replacement of equipment through projects. Over the lifespan of a haul truck, for example, there is no quantifiable benefit for such a replacement other than sustainability. Some of these projects run into billions of rands.

The assumption that the person selected to do the survey will be well informed to answer the questions correctly may influence the results. Ideally one would have more than one person in one organization do the survey for validity, but the anonymous nature of the survey doesn't allow this kind of verification. This limitation may put data validity at risk; however, the approach taken for validation of data would have addressed this.

\section{Results}

The population of companies that fit the profile described and that were selected for this research is 43 . Only 20 of these companies responded, some only partly. This gives a response rate of $46.5 \%$. Some respondents did not complete all the questions, and the zero response questions were excluded from the analysis. Although all the companies contacted are known entities and the specific persons can be identified as the point of contact, the feedback is entirely anonymous. The research questions were answered individually in subsections to clearly separate the details and also to clarify different instances where projectification and project management have an impact.

- Research Question 1: Do mining companies have dedicated project management office (PMO) structures?

The 20 respondents' results showed a 55:45 spilt between a positive and a negative answer to this question. The correlation between the 'yes' and 'no' answers and the time and money dedicated to projects in the organizations is clear. The dedicated PMO set-up in an organization is 


\section{Projectification in the South African mining industry}

clearly dependent on the time and effort (both human and monetary capital) required to execute work. The importance of managing the project process correctly, or at least the perception of good project management, can be created by having a dedicated, specialist team to conduct project activities.

- Research Question 2: What percentage of company's working time is used for projects?

A total of 17 responses were received on this question. The data to answer this question was sourced by including a direct question for the hours worked $v s$ project hours worked in the survey. Future and past hours allocated to the project environment were also included to understand where the respondent is coming from and where their institution is heading. Figure 6 shows the changes in project work proportions for the respective organizations in the years 2014, 2019, and projected for 2024. The different respondents are annotated by the $\mathrm{Rx}$ value on the $\mathrm{x}$-axis and the percentage of work done in project form for that respondent on the y-axis.

The general feedback indicates that the portion of project work in companies is increasing or is expected to increase towards 2024. Projectification, it seems, is on the rise in these mining organizations. Now, generalizing this information for the entire mining industry in South Africa requires understanding that not all mining is equal. The company that does all its work in the project form will typically be an exploration-type mining operation that uses consultants and contractors. The entity in itself does not necessarily perform any work other than managing projects in the mining space. It may be the holder of the rights to mining activities without running the operations.

Figure 7 illustrates the feedback from respondents in an alternative manner. Each year is represented in a pie chart that indicates the percentage of respondents that conduct work in a project-orientated manner. For example, in 2014 only $6 \%$ of respondents spent between more than $75 \%$ of their hours on project work. The data indicates that project work is likely to increase in future.

In summary; the current level of projectification and the future prospect of projectification in the mining industry in South Africa seems to be somewhat stable. Although less than $30 \%$ of the time spent during a day is employed in project work, the general feedback from respondents indicates that this will increase through 2024. The slow adoption of the project way of work up to 2019 can be attributed to the production target orientation, attention to immediate, short-term activities to support the targets, and functional structure employed in the South African mining sector.

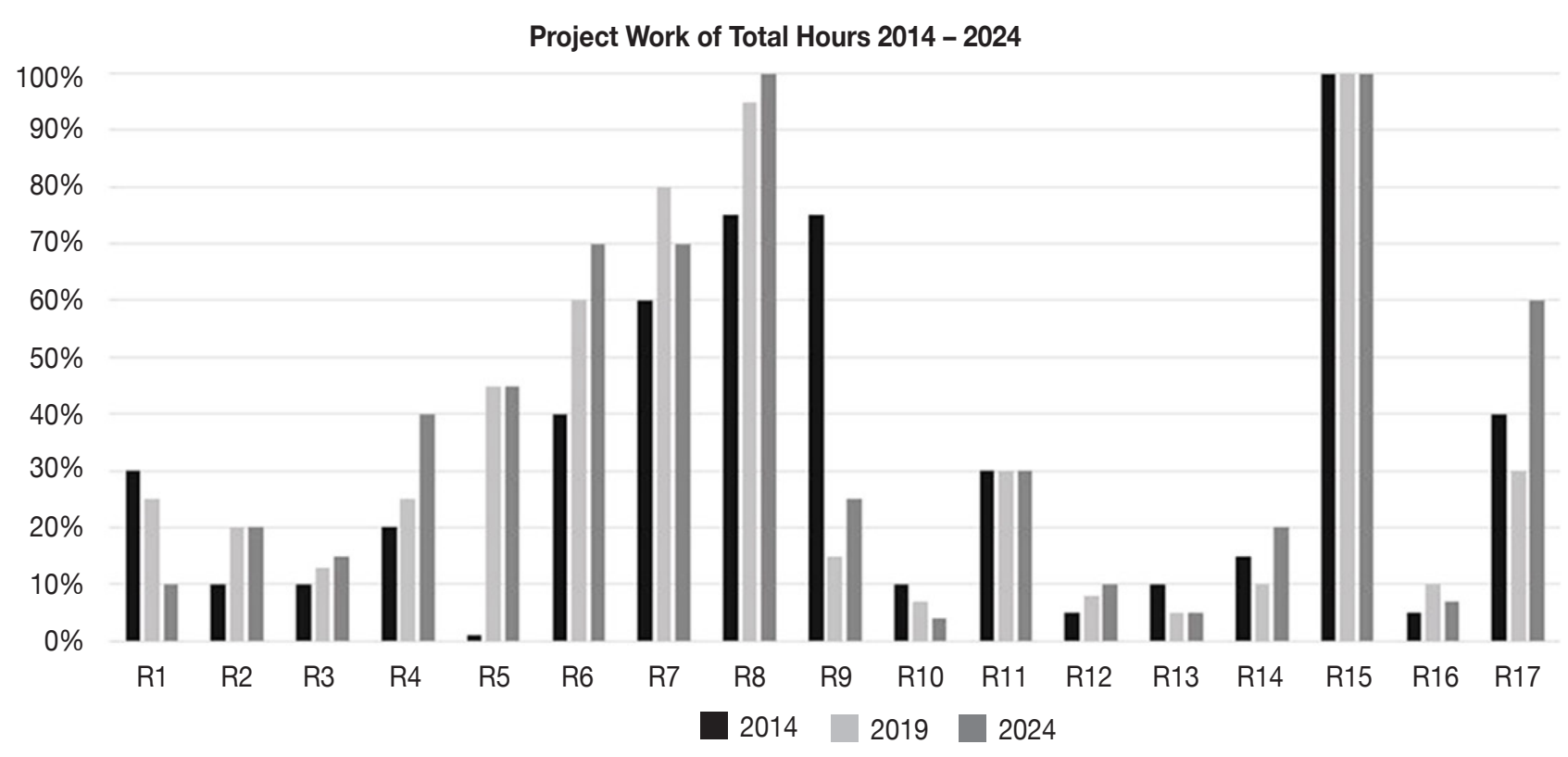

Figure 6-Proportion of project work in an organization
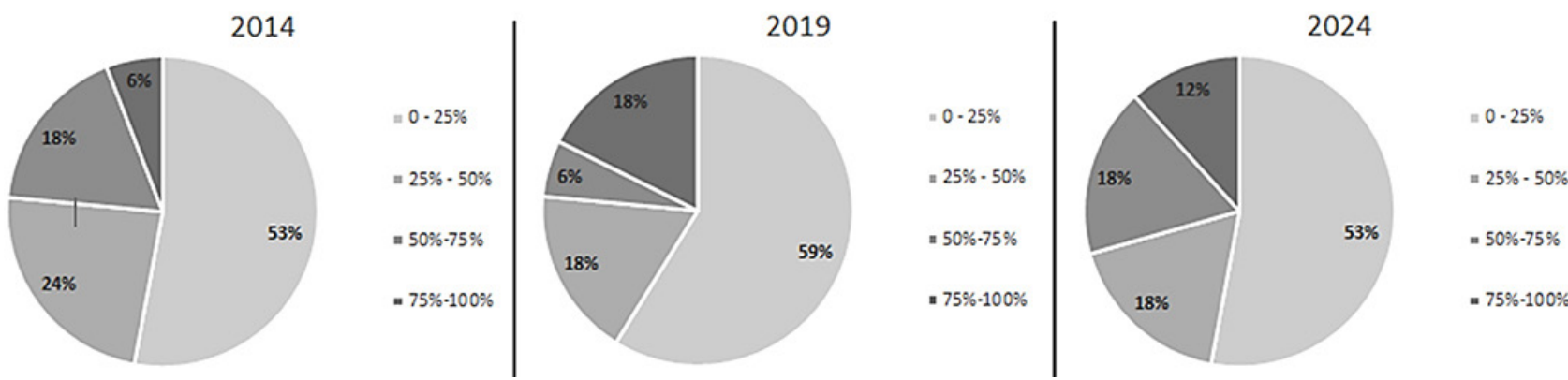

Figure 7-Percentage work hours to overall hours per respondent 


\section{Projectification in the South African mining industry}

> Research Question 3: What percentage of the South African mining industry can be defined as project orientated?

Being project orientated entails that one focuses on projects as a result of the value that is realized by those projects. To determine what percentage of the South African mining industry is project orientated, one can look at the value generated by projects for the respective companies. One can also investigate the operational characteristics in the companies evaluated. To do so, five statements made in the survey were aimed at obtaining clarity regarding the prevalence of temporary structures, the amount of work invested in projects, and the importance assigned to temporary work. The five statements on which responses were requested are listed below:

ST1 - Our firm is characterized by a high level of temporariness

ST2 - Most of the activities in our firm are conducted within projects

ST3 - Most of the work in our firm is invested in projects

ST4 - Much of the work done in our firm is attributable to temporary organizations

ST5 - Temporary work has in general a high importance in our firm.

The respondents were requested to evaluate each statement on a Likert scale with seven options from 'strongly disagree' to 'strongly agree'. The analysis of Likert data is a contentious issue because the data is not continuous. Nonparametric tests need to be applied to determine an effect in the ordinal data, but there is also a concern that the probability of detection of such an effect is limited because of spasmodic data. In this case, no comparisons will be done between data-sets and therefore the probability of success in applying nonparametric tests like the Mann-Whitney or t-test is reduced.

Based on this, the decision was made to present the percentage of project orientation in the mining industry in South Africa as the percentage of results in the positive side of the Likert scale. Figure 8 depicts the responses in a stacked bar graph to illustrate the negative and positive responses from the respondents. The black vertical centre line indicates the zero value in the scale where the disagree options have been assigned negative numbers and the agree options positive numbers. The 'neither agree nor disagree' option has been divided between positive and negative sides of the zero line.

It is clear that the bulk of the responses are on the negative side of the neutral line. The negative to positive ratio is 60:40 and is based on the sum of the number of responses to each statement (for example, Statement 1 had 12 negative responses $(-12)$ and 7 positive responses). This indicates that there is a low percentage or level of project orientated organizations in the South African mining industry. This low number can be attributed to the issues described earlier. Mining in South Africa is not yet completely developed in the project space and one can understand the lower projectification values as described here.

- Research Question 4: How does South Africa compare with developed economies?

The comparison to developed economies was done by comparing the South African mining industry with the the economies of Germany, Norway, and Iceland (Schoper et al., 2018). This comparison is shown in Figure 9.

The South African mining industry compares well with the findings for the developed economies. The comparison with the developed nations aims to support the evidence that projectification, as it is now understood, is on the rise in the South African mining industry and that this is a current trend in large industries and economies. A steady growth in project-type

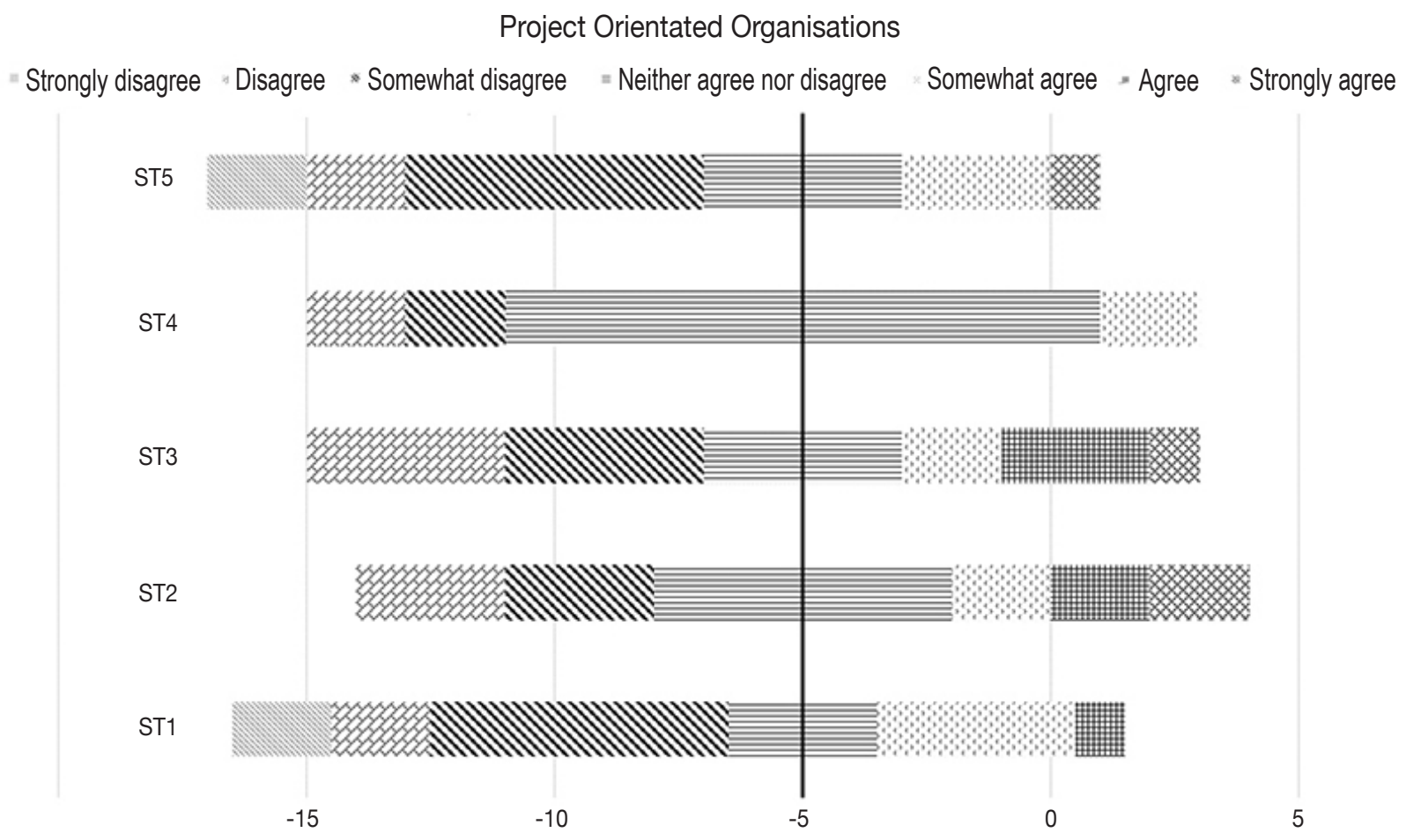

Figure 8-Percentage project orientation in the South African mining industry 


\section{Projectification in the South African mining industry}

work in all industries in the developed economies is expected, as is the case in the surveyed companies for the mining industry. The growth in technology and the need to control outcomes more precisely in an actively changing environment has necessitated the project approach in all walks of life. The trends depicted in Figure 9 are synonymous with the conclusions reached by Schoper et al. (2018), Midler (1995), and Jensen, Thuesen, and Geraldi (2016). Projectification is a 'human condition' that can be found in all industries and across all economies. Some environments take longer to become projectified than others, as is the case with the South African mining industry.

\section{Conclusions}

Considering the broad impact that mining has on the South African economy, a deeper investigation needs to be done on the impact projectification can have on the industry. From the surveyed responses it can be concluded that the level of projectification has not reached that observed in the telecommunication industry, which has higher project turnaround times.

Mining houses traditionally manage projects as part of their operational processes and these projects are not necessarily reflected in the answers provided in the survey. The value of some expansions in underground works, for example, may be in the medium project size classification and not be recorded in this survey feedback. This modus operandi limits the exposure that project management as a field of study has in the mining industry. The authors, having conducted projects with the some of the largest mining companies in South Africa, can relate to this shortcoming. The formal application of project management principles and thus the overall projectification in the mining industry in South Africa is not yet as refined as may be the case in other industries.

The majority of the respondents have dedicated PMOs (55\%), but the application thereof may be where the detail should be analysed further. The types of projects that these PMOs execute are mainly in the HR and marketing space. Pure technical work seems to be outsourced more than handled internally. Although the type of projects the PMO executes is not really relevant in the projectification space per se, it is significant in the mining industry. The levels of projectification will definitely be impacted if internal PMOs conduct more mining-related or technical projects.

In reviewing the level of projectification in the mining industry in South Africa, it became clear that the current status and outlook for future projectification looks to be stable. The Schoper et al. (2018) definition was used to determine the level of projectification and it is clear that projectification in the mining industry has grown in the last five years. It may be concluded that the level of projectification in the mining industry can be linked to the performance of the industry as a whole. It can also be concluded from the results that projectification in this industry is likely to decline if the decline in the overall industry and the associated economy continues. The current stable outlook for projectification is heavily dependent on the optimism of the respondent.

The projectification level and the project orientation of the mining industry are directly linked. The prevalence of temporary organizations and importance of temporary work are directly linked to the levels of projectification in the organization. Project orientation can be linked to the ability of the mining industry to expand and grow. In the ten years covered in this study, the South African economy has not grown and the mining industry has contracted significantly. Thus, it can be concluded that the percentage project orientation in the mining industry will follow the same growth curve as projectification.

The South African mining industry compares well with findings for the developed economies. Although the overall projectification is low, some growth is expected. This growth may be attributed to changes in operational approach to manage the effects of a slowing economy and other factors that impact mining operations daily. The comparison with developed economies needs to be further investigated to understand the overall projectification of the South African economy. The mining industry alone does not provide a holistic view of the levels of projectification in the country. One must also consider the inherent differences between the developed and developing economies.

This study covers the projectification of one-tenth of the South African economy. It adds value to the project management

SA Mining vs Developed Economies

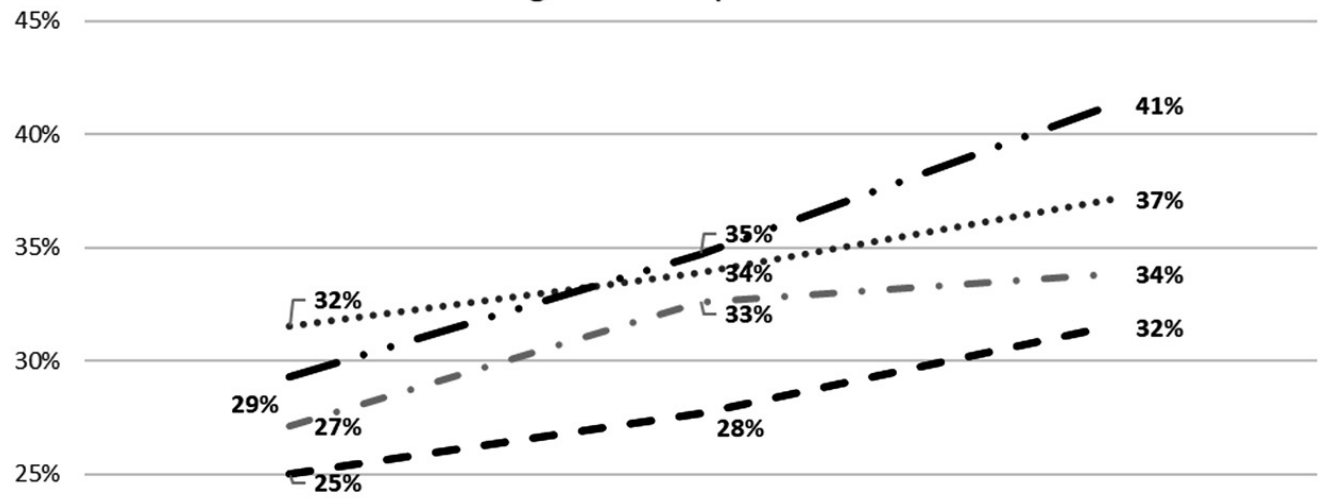

$20 \%$

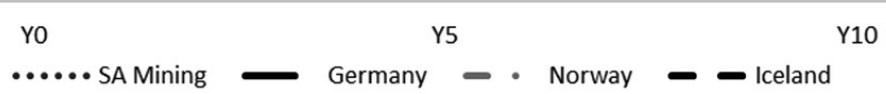

Figure 9-Projectification; South African mining vs developed economies over 10 years 


\section{Projectification in the South African mining industry}

knowledge area but excludes a significant part of the entire picture. It is recommended that a complete projectification study is done on the economy as a whole. This will better explain the impact project management has on the way work is done and what the approach to company structures, both from a human and other resource points of view, should be. As regards the mining industry; further study at a business unit level may provide more detailed results for projectification as viewed or perceived from a micro level and not from a corporate level.

By understanding the level of projectification in a specific economy, industry and/or business unit; decisions regarding resource allocation, in all forms and shapes, can be made to impact the work performance of those resources and essentially the bottom line of economy, industry and/or business unit. For example; projectification impacts the way organizations are structured, the way finances are structured and the effectiveness of delivering a service or a product. Knowing to what level an organization is projectified will benefit that organization in all these areas of decision-making.

\section{References}

AltinKayA, A. 2006. Cultural differences in international projects. A research study at Ericsson. MSc dissertation, Chalmers University of Technology, Gothenburg, Sweden. http://publications.lib.chalmers.se/records/fulltext/25690.pdf

Analysis Project. Not dated. Ethics in public administration I Code of conduct in public administration. http://analysisproject.blogspot.com/ [accessed 4 August 2018].

Aubry, M., Hoвbs, B., and Thuillier, D. 2007. A new framework for understanding organisational project management through the PMO. International journal of Project Management, vol. 25, no. 4. pp. 328-336.

Aubry, M., Hoвbs, B., and Thulluler, D. 2009. The contribution of the project management office to organisational performance. International Journal of Managing Projects in Business, vol. 2, no. 1. pp. 141-148.

BREDIN, K. and SoDERLund, J. 2006. Perspectives on human resource management: an explorative study of the consequences of projectiffication in four firms. International Journal of Human Resources Development and Management, vol. 6 , no. 1 pp. $92-113$.

BREDIN, K. and SoderLund, J. 2011. The HR quadriad: A framework for the analysis of HRM in project-based organizations. International Journal of Human Resource Management, vol. 22, no. 10. pp. 2202-2221.

Cicmil, S., Lindgren, M., and PAckendorfF, J. 2016. The project (management) discourse and its consequences: on vulnerability and unsustainability in project-based work. New Technology, Work and Employment, vol. 31, no. 1. pp. 58-76.

Cooke-Davies, T., Schlichter, J., and Bredillet, C. 2001. Beyond the PMBOK guide. Proceedings of the 32nd Annual Project Management Institute 2001 Seminars and Symposium, Nashville, TN. The Project Management Institute, Newtown Square, PA.

Crawford, J.K. and Pennypacker, J.S. 2001. The value of project management: Proof at last. Proceedings of the PMI 2001 Seminars \& Symposium, 2001. The Project Management Institute, Newtown Square, PA. pp. 1-10.

Crawford, L., HobBs, B., and Turner, J.R. 2006. Aligning capability with strategy: Categorizing projects to do the right projects and to do them right. Project Management Journal, vol. 37, no. 2. pp. 38-50.

De Roolj, M.M.G., Janowicz-Panjaitan, M., and Mannak, R.S. 2019. A configurational explanation for performance management systems' design in project-based organizations. International Journal of Project Management, vol. 37, no. 5. pp. 616-630.

Drob, C. 2009. The evolution of the project management. Studies and Scientific Researches. Economic Edition, no. 14. pp. 31-34.

ETiKAn, I., MusA, S.A., and AlKASSim, R.S. 2016, Comparison of convenience sampling and purposive sampling. American Journal of Theoretical and Applied Statistics, vol. 5, no. 1. pp. 1-4.
Hudson, L., and Ozanne, J. 1988. Alternative ways of seeking knowledge in consumer research. Journal of Consumer Research, vol. 14, no. 4. pp. 508-521.

ISO 21500. 2012. Guidance on project management, 1st edn. International Organization for Standardization, Geneva.

Jensen, A., Thuesen, C., and Geraldi, J. 2016. The projectification of everything: Projects as a human condition. Project Management Journal, vol. 47, no. 3 . pp. 21-34.

Kuprenas, J.A. 2003. Implementation and performance of a matrix organization structure. International Journal of Project Management, vol. 21, no. 1. pp. 51-62.

Lester, E.I.A. 2017. Project definition. Project Management, Planning and Control. 7th edn. Butterworth-Heinemann. pp. 1-5.

Maylor, H., Brady, T., Cooke-Davies, T., and Hodgson, D. 2006. From projectification to programmification. International Journal of Project Management, vol. 24, no. 8. pp. 663-674.

Metcalfe, B. 1997. Project management system design: A social and organisational analysis. International Journal of Production Economics, vol. 52, no. 3. pp. 305-316.

MidLER, C. 1995. "Projectification" of the firm: The Renault case. Scandinavian Journal of Management, vol. 11, no. 4. pp. 363-375.

Nicholas, J. and Steyn, H. 2017. Project Management for Engineering, Business and Technology. 5th edn. Routledge.

NelWamondo, P. and Pretorius, J. 2018. Application of the event chain project management methodology to a mining stope. Journal of the Southern African Institute of Mining and Metallurgy, vol. 118, no. 12. pp. 1233-1242.

PACKENDORFF, J. and Lindgren, M. 2014. Projectification and its consequences: Narrow and broad conceptualisations. South African Journal of Economic and Management Sciences, vol. 17, no. 1. pp. 7-21.

PAyne, J.H. and Turner, J.R. 1999. Company-wide project management: the planning and control of programmes of projects of different type. International Journal of Project Management, vol. 17, no. 1. pp. 55-59.

Phillis, R. and Gumede, H. 2011. A case study on stoping shift buffering at Impala Platinum: A critical chain project management perspective. Journal of the Southern African Institute of Mining and Metallurgy, vol. 111, no. 11. pp. 793-800.

Schoper, Y.-G., Wald, A., Ingason, H.T., and Fridgeirsson, T.V. 2018. Projectification in developed economies: A comparative study of Germany, Norway and Iceland. International Journal of Project Management, vol. 36, no. 1. pp. 71-82.

Shenhar, A.J. and Dvir, D. Project management evolution: Past history and future research directions. Proceedings of the PMI Research Conference, 2004. Project Management Institute, Newtown Square, PA:. pp.11-14.

Statistics South Africa. 2018. Mining: Winners and losers of 2017. http://www. statssa.gov.za/?p=10963 [accessed 5 August 2018].

TURNER, J.R. and MüLLER, R. 2003. On the nature of the project as a temporary organization. International Journal of Project Management, vol. 21, no. 1. pp. 1-8.

USC Libraries. Not dated. Organizing your social sciences research paper: Quantitative methods. University of Southern California. https://libguides.usc. edu/writingguide/quantitative [Accessed 29 August 2018].

Van der Linde, J. and Steyn, H. 2016. The effect of a project management office on project and organisational performance: A case study. South African Journal of Industrial Engineering, vol. 27, no. 1. http://sajie.journals.ac.za/pub/article/ view/1114/672

Van Staden, P.J., Steyn, H., and Schnetler, R. 2015. Characteristics of matrix structures, and their effects on project success. South African Journal of Industrial Engineering, vol. 26, no. 1. pp. 11-26.

WEAVER, P. 2006. A brief history of project management. APM Project, vol. 19, no. 11. https://mosaicprojects.com.au/PDF_Papers/P061a_A_Brief_History_of_ Project_Management.pdf

WнітTY, S.J. 2009. New philosophy of project management: An investigation into the prevalence of modern project management by means of an evolutionary framework. PhD dissertation, University of Queensland.

WhiтTY, S.J. and Schulz, M.F. 2007. The impact of Puritan ideology on aspects of project management. International Journal of Project Management, vol. 25, no. 1. pp. 10-20. 